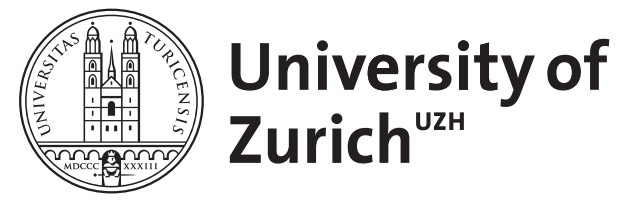

Zurich Open Repository and Archive

University of Zurich

University Library

Strickhofstrasse 39

CH-8057 Zurich

www.zora.uzh.ch

Year: 2014

"Following one's desire" ( kāmacāra ): On a Characterisation of Freedom in Vedic Literature and the Mahābhārata

Malinar, Angelika

Posted at the Zurich Open Repository and Archive, University of Zurich ZORA URL: https://doi.org/10.5167/uzh-110394

Journal Article

Originally published at:

Malinar, Angelika (2014). "Following one's desire" ( kāmacāra ): On a Characterisation of Freedom in Vedic Literature and the Mahābhārata. Asiatische Studien, 68(3):757-782. 


\section{ASIATISCHE STUDIEN ÉTUDES ASIATIQUES}

ZEITSCHRIFT DER SCHWEIZERISCHEN ASIENGESELLSCHAFT REVUE DE LA SOCIÉTÉ SUISSE-ASIE

EDITOR OF THIS ISSUE

Maya Burger, Lausanne

EDITOR-IN-CHIEF

Rafael Suter, Zürich

\section{DE GRUYTER}


EDITORIAL BOARD Blain Auer, Lausanne. Norman Backhaus, Zürich. Wolfgang Behr, Zürich. Daria Berg, St. Gallen. Maya Burger, Lausanne. David Chiavacci, Zürich. Bettina Dennerlein, Zürich. Karénina Kollmar-Paulenz, Bern. Anke von Kügelgen, Bern. Angelika Malinar, Zürich. Annemarie Mertens, Zürich. Silvia Naef, Genève. Maurus Reinkowski, Basel. Andrea Riemenschnitter, Zürich. Ulrich Rudolph, Zürich. Reinhard Schulze, Bern. Pierre Souyri, Genève. Raji C. Steineck, Zürich. Ingo Strauch, Lausanne. Christoph Uehlinger, Zürich. Nicolas Zufferey, Genève.

Publiziert mit Unterstützung der Schweizerischen Akademie der Geistes- und Sozialwissenschaften. Publiée avec le soutien de l'Académie suisse des sciences humaines et sociales.

Published with the support of the Swiss Academy of Humanities and Social Sciences.

\section{SAGW} ASSH 


\section{Inhaltsverzeichnis - Table des Matières - Contents}

\section{Aufsätze - Articles - Articles}

Blain Auer

Dial $\mathbf{M}$ for Murder: A case of passion killing, criminal evidence and sultanic power in Medieval India — 667

Maya Burger

La Sarvāngayogapradīpikā de Sundardās : une classification des chemins de yoga au 17 e siècle — 683

Birgit Kellner and John Taber

Studies in Yogācāra-Vijñānavāda idealism I: The interpretation of Vasubandhu's Vimśrikā 709

Angelika Malinar

“Following one's desire" (kāmacāra): On a characterisation of freedom in Vedic literature and the Mahābhārata — 757

Fabrizio Speziale

The Persian translation of the tridoșa: lexical analogies and conceptual incongruities -783

Ingo Strauch

Looking into water-pots and over a Buddhist scribe's shoulder - On the deposition and the use of manuscripts in early Buddhism — 797

Angela Wagner-Hohenberger

On the composition of parallel versions of the story "The appearance of the linga" (lingodbhava) in the Purāṇas — 831

\section{Rezensionen - Comptes rendus - Reviews}

Philippe Bornet

Recent textbooks on religions in South Asia 849 
Hang Lin

Fan, Chengda, translated by James M. Hargett. Treatises of the Supervisor and Guardian of the Cinnamon Sea: The Natural World and Material Culture of

Twelfth-Century China - 855

Joseph Ciaudo

Isay, Gad C. The Philosophy of the View of Life in Modern Chinese

Thought -859

Aline Schlaepfer

Milich, Stephan / Pannewick, Friederike / Tramontini, Leslie (eds). Conflicting Narratives: War, Trauma and Memory in Iraqi Culture — 865

Friederike Assandri

Pries, Andreas H. / Martzolff, Laetitia / Langer, Robert / Ambos, Claus (eds.).

Rituale als Ausdruck von Kulturkontakt. „Synkretismus" zwischen Negation und Neudefinition - 869

Zhang Minyu

Strnad, Jaroslav: Morphology and Syntax of Old Hindī: Edition and Analysis of One Hundred Kabīr vānī Poems from Rājasthān — 879

Ulrich Brandenburg

Worringer, Renée. Ottomans Imagining Japan. East, Middle East, and Non-

Western Modernity at the Turn of the Twentieth Century — 883 
Angelika Malinar

\title{
"Following one's desire" (kāmacāra): On a Characterisation of Freedom in Vedic Literature and the Mahābhārata
}

\begin{abstract}
The compound kāmacāra is in Vedic literature connected to ideas of freedom which are different from the well-known ones often associated with immovability and changelessness as the characteristic features of the "self" (ätman) or the "absolute" (brahman), and of "liberation" (mokșa, mukti) as a state beyond pleasure and desire. It rather refers to a semantic register of freedom which is used in order to describe states of independence and liberty obtained in the after-life in which immortality is defined not as freedom "from", but as freedom "to". Correspondingly, kāmacāra is used in connection with notions of autonomy expressed by the words svatantra or svatantratā (independence) and svarāj (self-rule), and not with the semantics of mukti and mokșa, the terms frequently used for the freedom that accrues through "liberation" or "release" from worldly existence. New ascetic teachings on the extinction of all desire as well as new interpretations of ritual action and individual agency (karman) did not result in completely removing the idea of a state of "following one's desire" from the spectrum of salvific ideas, but rather in its being reinterpreted vis-à-vis "higher" goals. While the speculations about the freedom to be obtained in future existences are in some Vedic texts intrinsically connected with notions of the "self" (ätman) and the realm of brahman, they become in the Mahābhārata features of particular regions and agents. Furthermore, kāmacāra becomes a topic in negotiating gender, and more specifically, marital relations and is made a characteristic feature of times and places in which laws of possession do not rule social relationships. The analysis of the occurrences of the compound in Vedic literature and the epic aims at tracing semantic shifts and changing referential frameworks of meaning.
\end{abstract}

DOI 10.1515/asia-2014-0058

Angelika Malinar: Institute of Asian and Oriental Studies, Indian Studies, University of Zurich, Rämistrasse 66/68, 8001 Zürich, Switzerland. E-mail: angelika.malinar@aoi.uzh.ch 
Although occasionally noticed in studies on Vedic literature, the occurrences and implications of the expression kāmacāra have not been analyzed in detail. The compound occurs, in particular, in contexts which deal with a state of freedom that allows one to do what one wants and to move around freely. Correspondingly, English translations usually accentuate either the "movement" aspect, such as in "moving freely" or "complete freedom of movement", or the "freedom" aspect, as in "following one's own desires" or "complete freedom". Both aspects converge quite nicely in the German rendering "Wandeln nach Wunsch". ${ }^{1}$ The compound is frequently used in order to qualify a state of freedom in positive terms, that is, not as freedom "from", but as freedom "to". In the following, the usage of kāmacāra and the ideas of freedom associated with it shall be traced in Vedic and epic literature. This may yield some insight into the ways in which the relationship between the affirmation of the pursuit of desire and pleasure ( $k \bar{a} m a)$ in the older Vedic literature and its general rejection in the evolving ascetic discourse is negotiated in the these texts. The compound kāmacāra occurs in texts concerned with "higher" forms of existence - such texts both precede as well as follow formulations of doctrines postulating the termination of karman and $k \bar{a} m a$. While the speculations about the freedom to be obtained in future existences are in some Vedic texts intrinsically connected with notions of the "self" (ätman) and the realm of brahman, the idea of kämacāra becomes in epic literature a feature of particular cosmic regions and is connected to the discourse on the freedom of women and thus to issues of gender.

\section{Kāmacāra in the Brāhmanas: Free movement in the afterlife}

The point of departure of this particular idea of freedom which connects following one's pleasure with free movement can be seen in the intense concern for fulfilling desire that is ingrained in the Vedic ritual tradition. In one of the hymns to Soma in which this concern is formulated, we find the expression anukämam caranam which can be seen as the precursor of the compound kāmacāra. ${ }^{2}$ In Rgveda 9.113.9 Soma is asked to make the sacrificer immortal in the "highest firmament" where one moves freely (yatrānukāmam caranam): "Where one can move following one's desire in the three-vaulted, three-heavened [place] of

1 In later texts the compound is also used in the sense of hedonistic, selfish behaviour (see below).

2 See Horsch 1971: 144, note 57. 
heaven, where there are worlds filled with light, O drop, flow around for Indra." 3 The passage to the other world is envisioned as obtaining an immortality characterized by free movement, fulfilment of all desires and happiness. This is again stated at the end of the hymn: "Where joys and delights, elations and exaltations dwell, where the desires of desire are obtained, there make me immortal, 0 drop, flow around for Indra." 4

This depiction of a state of immortality connected to the idea of anukāmam caranam and to the fulfilment of the "desires of desire" persists in later Vedic texts, which contain also the earliest occurrences of the compound kāmacāra. Some attention has been given by scholars to a passage in the JaiminiyaUpanișad-Brāhmaṇa (JUB) which describes how a (deceased) sacrificer meets the different Vedic gods in their heavenly abodes. In moving from one region to the next, he receives from each god what he had sacrificed to him. He then asks the god to bring him to the next region. ${ }^{5}$ When he reaches the moon (the abode of the ancestors), he asks to be brought to the world of brahman, but instead he is returned to the sun, who dispatches him again to the moon. At this point the following explanation is given: "He thus wanders to and fro between these divinities. This is the end (anta). There is no carrying forth from beyond this [limit]. And all the worlds beyond (i.e. that came before) this [limit] of which we have spoken, they are all obtained, they are all conquered, in all of them there is unrestricted movement for him who knows thus. If he should wish: 'May I be born here again', on whatever family he might fix his thoughts, be it a Brāhman-family, be it a royal family, into that he is born. He keeps on ascending to this world fore-knowing." 6

3 yátrānukāmám cáraṇaṃ trināké tridivé diváḥ / lokấ yátra jyótișmantas tátra mấm amṛtaṃ kṛdhi indrāyendo pári srava /9.113.9/ (tr. Jamison \& Brereton 2014, Vol. 3: 1366).

4 yátrānandấs ca módāś ca múdaḥ pramúda āsate / kấmasya yátrāptấh kāmās tátra mấm amṛtạ̣ kṛdhi índrāyendo pári srava //9.113.11/ (tr. Jamison \& Brereton 2014, Vol. 3: 1366).

5 There are several depictions of such journeys through the yonder-worlds, such as, in the Kauśitaki-Upanișad, wherein the passage is connected to knowledge-tests; see Thieme 1971. Related to this idea of roaming in the afterlife is the circular movement through the "wheel of sacrifice", describing the return of the "deceased" to the human world. Both models are based on the idea that upon death the individual is transformed into a sacrificial offering and thus some (often unspecified) part of him or her continues to exist.

6 sa eva te devate anusạ̣carati /2// eșo 'nto 'tah paraḥ ta pravāho nāsti / yān u kāṃś cātaḥ prāco lokān abhyavādișma te sarva āptā bhavanti te jitās teșv asya sarveșu kāmacāro bhavati ya evam veda /3// sa yadi kāmayeta punar ihājāyeyeti yasmin kule 'bhidhyāyed yadi brāhmaṇakule yadi rājakule tasminn ājāyate / sa etam eva lokam punah prajānann abhyārohann eti /4// JUB 3.28.2-4; tr. Oertel 1896: 188. 
The precondition for obtaining kāmacāra is "knowing thus", ${ }^{7}$ which apparently refers to knowing the "end" (anta) of the worlds as well as all the worlds that come before it. Oertel's translation of asya kāmacāro bhavati evam veda ("there is unrestricted movement for him who knows") stresses one important connotation of kāmacāra, the freedom of movement. It highlights freedom as the state of being able to move without the restrictions and obstacles which otherwise keep people in place. The other connotation of kāmacāra (to follows one's own pleasure) comes into play as well when the element of "wishing" is emphasized and it is explained that one is free to choose where one is born again. This not only includes the heavenly worlds one obtains upon death, since one may also choose to be born again "here", that is, in the social world of human beings (preferably in a well-off social class). ${ }^{8}$ On the practical side, when it comes to the realization of any such wish, the state of kämacāra appears to be intrinsically connected to a mental process, namely, the direction of one's thoughts and intentions (abhi+dhyai) towards the object of desire. This obviously serves to make one's wish come true. In contrast to texts that mirror the influence of ascetic ideas (for instance, in Yoga texts) no further requirements for obtaining this state of being able to freely realise one's intentions are mentioned, except for the knowledge of the "worlds" and their limit (anta). This alone suffices in order to allow free activities with respect to what is within this limit.

Two passages in the Gopatha-Brāhmana (GoBr) place this idea of "moving freely" or "Wandeln nach Wunsch" in the context of alternative, less desirable notions of an afterlife on offer, namely, "re-death" (punarmrtyu) and return to the world (punarājāti). ${ }^{9}$ In GoBr 1.1.15 it is said to be the reward for carrying out atonement rituals (prāyaścitti); in 1.3.22 it is connected to rituals which "gratify desires" (kāmapra) and demand the knowledge of Vedic chant (sāman). In both passages, it is stated that "he who knows thus shines forth, being one who is moving freely

7 On evam veda as a characteristic feature of propagating the "intrinsic power of knowledge" in the Upanișads, see Edgerton 1929: 97-99; 103ff. While he is analysing an important aspect of these texts, his conclusions about their "magical" character are not further explained by means of a definition of "magic" as an analytical category.

8 In his discussion of this passage Schmithausen (1995: 52-53) views the idea of choosing "elite" families as the realm of rebirth as a further development of the older "tribal" idea of ideally being reborn in one's own family and thus as being indicative of a stronger demarcation of social differences.

9 These passage are mentioned by Horsch (1971: 143-144) who views the state of "nach Belieben Wandeln" as representing one of the older concepts preceding the transmigration doctrine. 
(following his pleasure) in all worlds". ${ }^{10}$ In all these passages, the attainment of such a state of freedom is solely based on ritual knowledge. Furthermore, it is important to notice that the state of "following one's own wish" in the afterlife is not connected to any particular condition or wish at the moment of death. This idea becomes increasingly important in other (probably later) texts, and continues to be so in religious traditions which postulate that the thoughts and wishes one has in the hour of death directly influence one's experiences in the afterlife. ${ }^{11}$

\section{Kāmacāra in the Chāndogya-Upaniṣad: "Self-Rule"}

While the treatment of kāmacāra in the Chāndogya-Upanișad (ChU) is connected conceptually and historically to the JUB, it also reveals the impact of the new notions of the "self" (ätman) and of brahman as a state of immortality. Furthermore, this state is no longer exclusively connected to death and the afterlife. The idea of kämacāra plays a prominent role in the seventh chapter of ChU which contains the instruction which Nārada, the brahmanical sage par excellence, receives when he approaches Sanatkumāra in order to learn about the "self". Nārada explains that he is only "a knower of mantras" (mantravid), but not of the "self" (na àtmavid) and he therefore lacks the means for overcoming suffering (śoka; ChU 7.1.3). The nature of this suffering is not explained further, but the instruction allows us to draw some conclusions about it. In his response, Sanatkumāra presents a list of sixteen entities or realms which should be honoured or venerated $(u p a+a s)$ as brahman, starting with nāma, name, and ending with bhüman, abundance or plenitude. The list comprises different registers of what can be viewed as constituents of beings as well as of the world these beings live in. The way in which this list is presented suggests that the elements are arranged hierarchically with each element surpassing the next, i.e. "name" is surpassed by "speech" ( $v \bar{a} c)$ as the element that gives names; higher than speech is manas, the mind being the element through which speech is formed etc. At the end of the instruction further aspects of the relationship between the elements are

10 kāmacāro 'sya sarveșu lokeșu bhāti ya evam veda; GoBr 1.1.15 = 1.3.22. In the ŚatapathaBrāhmaṇa the obtainment of kāmacāra is mentioned as a motive for certain ritual actions (see ŚBr 2.2.3.22, 2.3.4.1, 6.7.3.55).

11 This point is emphasized by Schmithausen (1995: 55); for the importance of the "hour of death", see Edgerton 1927. 
mentioned, which qualify this hierarchy as an assemblage of the elements (see below). ${ }^{12}$

Important for the present discussion is that all elements are characterized as realms or dominions at the disposal of the one who honours them as brahman and eventually understands that they all constitute himself or "the self". This knowledge results in turning the elements into realms at the disposal of the one "who knows thus" and has obtained kāmacāra. The first realm explained by Sanatkumāra is "name" (nāma), which comprises the world of words and objects as given in the different branches of learning which Nārada, as a mantravid (knower of mantras), has already at his disposal, but still needs to understand and honour properly: "He who honours name as brahman to him accrues free movement (kāmacāra) in there - as far as name extends - for him who honours name as brahman" (ChU 7.1.5). As Nārada already enjoys command over the realm of name, which is obviously not enough for him (as he came for instruction in order to overcome suffering), it comes as no surprise that he asks if there is something "more" (bhūya). Sanatkumāra states that "speech" is "more" since it is what names things. Again it is explained that honouring speech as brahman results in obtaining kāmacāra, to do what one wants - as far as this realm extends. In the same way, each realm is explained as something to be "honoured" as brahman and this results in having it at one's disposal. The instruction concludes with bhüman, abundance or plenitude, which is defined as sukha, happiness. It is explained that sukha is the only reason for acting: "When one obtains pleasure, then one acts". ${ }^{13}$ This is why happiness is the only thing one needs to understand (sukham tv eva vijijñāsitavyam; 7.22.1). Nārada replies that this is indeed what he wants to understand. This reply can be read as a reference to Nārada's motive for seeking instruction, namely, the removal of suffering (7.1.3), which seems to consist primarily in the lack of happiness and pleasure entailed in one's actions. Suf-

12 In his discussion of the list, Deussen (1921: 171-172) emphasizes the hierarchy implied in the addition of ever "higher" spheres to be venerated as brahman, but also mentions his "Befremden" (disconcertment) with respect to some of the elements listed. In contrast to this, Kunst (1978: 69) points out that the hierarchy does not resemble the model of a "hierarchical evolution" in which one phenomenon proceeds from another. Instead, "each element stands in its own right as a weaker or stronger link in the chain of categories. The internal cause-and-effect relationship between the preceding and succeeding element is rather underplayed." While Kunst is certainly right that we are not dealing with a causal hierarchy, the idea of "weaker and stronger" links awaits substantiation as does his claim that causality depends on the mumukșu (seeker of liberation), a term that does not occur in ChU 7. As a consequence, he interprets the state of kāmacāra as an experience of limitation based on the determinism implied in the cosmology presented in ChU 7 (Kunst 1978: 70). This seems doubtful.

13 yadā vai sukhaṃ labhate 'tha karoti, 7.22.1 
fering is implicitly defined as being caused by restrictions, lack of freedom and being dependent on others, as can be seen in the depiction of the happiness that accrues from understanding bhūman. ${ }^{14}$

Sanatkumāra explains that bhūman, abundance, completeness, is a state of "greatness" and "might" (mahiman), not of smallness or shortage (alpa), in which one does not recognize any other but oneself. Since this greatness belongs to oneself (svamahima), it is not dependent on "others" as is the case in ordinary life. Usually, "greatness" is measured by what "others" one possesses, that is, cattle, slaves etc. (anyo hy anyasmin; 7.24.2). In contrast to this, bhüman accrues when "I" (ahamkāra) recognizes that the self is in command of all elements, that it is "all" (sarvam). ${ }^{15}$ Being all, the self rules "all" since ruler and ruled are the same in the self-referential occupation of the self with itself. This recognition and the self-referentiality entailed in it are described as follows: "A man who sees it this way, thinks about it this way, recognizes it this way, being a man who is passionate about the self, who is sporting with the self, who mates with the self, who attains bliss with the self - he is his own ruler (svarāj; i.e. independent), in all worlds he follows his own pleasure (kāmacāra; moves freely). Then, those who know otherwise, they have others as rulers, their worlds are perishable, they lack the freedom to follow their own pleasure (akāmacāra) in all worlds."16

The freedom described here is based on understanding the relationship between the sixteen elements as being not only a hierarchy, but also as an assemblage of elements which are all equally held together and "ruled" by the self to which they belong. The self is primarily defined as the entity that has all these elements at its disposal and is therefore endowed with kāmacāra. The self is "all" because it owns the elements which constitute its plenitude and happiness (sukha). Therefore, knowledge of the self is the perfect antidote against the suffering entailed in being ruled by others and being restricted by the limitations implied in pleasures that are based on relationships of possession. ${ }^{17}$ As a conse-

14 There is no mentioning of suffering which emerges from the fundamental defects of existence, such as death etc., which are only mentioned in a verse at the very end of ChU 7.

15 In other Upanișads this interpretation of the self is identified by adding the attribute mahān, great or large; for an analysis of the notion of the "large ätman" and its subordination to "higher" entities in later texts, see van Buitenen 1968.

16 sa vā eșa evaṃ paśyann evaṃ manvāna evaṃ vijñānann ātmaratir ātmakrị̄a ātmamithuna ātmānandah sa svarāẹ bhavati / t asya sarveșu lokeșu kāmacāro bhavati / atha ye 'nyathāto vidur anyarājānas te kṣayyalokā bhavanti / teșām sarveșu lokeșv akāmacāro bhavati // ChU 7.25.2 /.

17 The final verse of ChU 7 ends on a slightly different note with its emphasis on the suffering which arises from death and illness, which is also removed through the knowledge that the self "obtains all" (sarvam appnoti; 7.26.2) and is therefore connected to varies forms and levels of existence. 
quence, the self is not defined as being separate from all corporeal existence while abiding in its own form (svarūpa) or as vanishing in an absolute state of being, but as possessing freedom of movement and as pursuing its desires (kāmacāra) since it is its own ruler (svarāj). This freedom is illustrated by drawing on ordinary relationships of power and command, in particular, of the position of the king. On the one hand, it is acknowledged that the king, or rather the "selfruler" is in the social world regarded as the epitome of power and "wholeness". ${ }^{18}$ Furthermore, he is the one who may move in his kingdom freely. ${ }^{19}$ On the other hand, it is very clearly stated that the freedom that accrues from the knowledge of the self differs from the relations between the ruler and the ruled that usually define the social world. Dependency is the key-term here for referring to the state of bondage that applies even to the king who is, when compared to his subjects, a relatively free man. Dependence not only means being subject to the rule of "another" (anya), i.e. a king, but more generally any form of existence defined by and based on "another" (anya), that is, all those things which ordinarily define power and freedom (cattle, peoples, territory etc.). In contrast to this, "self-rule" means freedom as being totally independent from anything other than oneself. This idea is depicted by using the ordinary ways of obtaining power (through possession) and representing the freedom that accrues from it (kingship) as the foil against which true freedom in the sense of "self-rulership" and "following one's own pleasure" is propagated.

The intention to distinguish kāmacāra and svarāj from ordinary relations of power and dependency is also discernible in ChU 8. In this chapter the idea of "free movement" becomes (again, like in JUB) connected to a state after death, while it was in ChU 7 primarily a state of "happiness" (sukha) and "plenitude" (bhüman) based on recognizing and possessing the self. Furthermore, brahmacārya (celibate life) is now postulated as being the precondition for obtaining kāmacāra. While Sanatkumāra explained in ChU 7 that each of the elements listed by him should be "honoured" as brahman, there was no mentioning of brahmacāra or brahmacārya as a specific precondition for obtaining knowledge of the self and, along with it, the state of kāmacāra. ChU 8 begins with the

18 The connection between kingship and "being the whole" has been analyzed by Proferes (2007: 144-152), who argues that in the Upanișads (for instance ChU 7) the earlier Vedic speculations about the relations between the king and his dominion were taken as a paradigm for new "esoteric spiritual ideas" (Proferes 2007: 148-149). On the use of svarāj in political contexts of modern India and its religious background, see Brown 1985.

19 The dominion-like character of the elements constituting the self and the connection of kāmacāra to ideas of kingship is pointed out by Sankara in his commentary on the passage: yathākāmacāraḥ kāmacaraṇam rājña iva svavișaye bhavati (like the freedom of movement a king has in his own territory) (Śankarabhāṣya ad ChU 7.1.5). 
well-known explanation of the self as the entity which resides in the "lotus" inside the body ("the city of brahman") containing all worlds (ChU 8.1.1-6). The self is not affected by the fundamental features of corporeal existence (death etc.), but rather is an entity "whose wishes come true" (satyakäma). This latter characteristic is repeatedly ascribed to the self in ChU 8 and it matches the state of kämacāra well. In ChU 8.1.5-6 it is pointed out that the self is not understood when construed along the lines of ordinary activities, which are as perishable as the body and are carried out only following the instructions or orders of others: "As subjects of a king here in this world settle down as instructed, and whatever frontier they covet - whatever region, whatever piece of land - they make a living on it; and as here in the world the possession of territory won by action comes to an end, so in the hereafter a world won by merit comes to an end. So, those here in this world who depart without having discovered the self and these real desires do not obtain complete freedom of movement (akāmacāra) in any of the worlds, whereas those here in this world who depart after discovering the self and these real desires obtain complete freedom of movement in all the worlds (kāmacāra)."20

This passage again stresses the undesirability of living a life in which one has to follow commands or instructions (anuśāsana) and is restricted to a specific field of activity. Being subject to rules and rulers is the ordinary state of dependent existence. Knowledge of self terminates this not by simply getting rid of it, but by obtaining a state of independence that allows one to do as one pleases. It is a state also devoid of "labour" (involved in living off the land) or, more generally, "productive activity" (karman), and it is therefore not subject to decay. It is a state of acting "for free", that is, without consuming resources or producing fruits, yet of being able to roam the worlds while one's "wishes come true".

This is put into more concrete terms in the description of the connection between desire and intention (samkalpa) in ChU 8.2. When one wishes to roam in the world of the fathers or that of the mothers, one should direct one's thoughts at them, that is, form a wishful intention (samkalpa), and they will appear: "Whatever may be the object of his desire, anything that he may desire - by his intention alone it rises up. And, securing it, he rejoices." 21 Those who do not

20 yathā hy eveha prajā anvāviśanti yathānuśāsanam / yaṃ yam antam abhikāmā bhavanti yam janapadam yam kṣetrabhāgaṃ tam tam evopajīvanti // 8.1.5 / tad yatheha karmajito lokah kṣìyata evam evāmutra punyajito lokaḥ kṣìyate / tad ya ihātmānam ananuvidya vrajanty etāṃś ca satyān kāmāṃs teșām sarveșu lokeșv a kāmacāro bhavati / atha ya ihātmānam anuvidya vrajanty etaṃs ca satyān kāmāmẹs teșāṃ sarveșu lokeșu kāmacāro bhavati // 8.1.6 / tr. Olivelle 1996: 275. Deussen emphasizes the aspect of "freedom" even more strongly when rendering (a)kāmacāra with "Leben in Unfreiheit” and "Leben in Freiheit" respectively (Deussen 1921: 190).

21 yam yam antam abhikāmo bhavati / yam kāmaṃ kāmayate / so 'sya saṃkalpād eva samuttișțhati | tena sampanno mahīyate || ChU 8.2.10. 
know the self will not be able to do so. The explanatory impact of this passage is based on the role of samkalpa, the "declaration of intent" which is one important element in the performance of Vedic ritual. By uttering the samkalpa, the patron of the sacrifice announces to whom he offers the sacrifice and for what purpose; thereby the fruits of the sacrifice are appropriated by him. In the ChU, samkalpa still provides the link between the self, the wish and its fulfilment, but it is a direct link, devoid of any priestly assistance or material investment. It is presented as a mental act that implies its own realization, and it seems to have the function of connecting the self with the powers or realms at its disposal. Its force seems to lie in the fact that it manifests the knowledge that the self is "all". A similar process is described in JUB 3.28.2-4 (see above) and ChU 8.2.10. In the former passage "directing one's thoughts at" (abhi+dhyai) the desired realm suffices for obtaining it. The mental power which puts the material world at one's command is an important topic in Yoga traditions as well. Knowledge and the mental acts that result from it overrule the spatial and temporal restrictions implied in corporeality and material dependency. Therefore, freedom of movement and action has to be construed also as being "for free", being exempt from the cycles of production and consumption. Yet, in ChU 8.4 a precondition for obtaining this freedom is mentioned that has not been mentioned in the other texts, namely, brahmacarya, "engaging in brahman", that is, living the celibate life of a student. ${ }^{22}$ It is explained that the self is like a dam which both connects as well as separates this world and the next. In order to cross over this dam, reach the world of brahman and obtain freedom to do as one pleases (kāmacāra; 8.4.3), one must practise brahmacarya. The concrete practices are further described in ChU 8.5, comprising certain ritual and ascetic practices such as observing silence (mauna).

In contrast to interpretations of the self as inactive, immovable and unchangeable and of the path that leads to its recognition as entailing the reduction of action and pleasure, the knowledge of the self as described in these passages results in an enhancement of pleasure and mobility by way of obtaining kāmacāra. This refers, primarily, to the freedom to exist in all worlds in any form one chooses. It is the freedom to do as one pleases while being restricted only by the limits of these worlds. In the JUB this state is connected only to a proper knowledge of these worlds and their limits, in the GoBr it is connected to specific ritual practices, and in the ChU it becomes a characteristic feature of knowing the "self". The latter entails a re-interpretation of the basis of this freedom. In ChU 7 the realms in which kämacāra is obtained are not the worlds of the Vedic gods

22 Olivelle renders brahmacarya as the life stage of a "celibate student”, Deussen (1921: 188) explains "Leben als Brahmanschüler in Studium und Entsagung”. 
reached by the deceased sacrificer, but the constitutive elements of corporeal existence. These elements are explained as emerging from the self which one (i.e. the "I"-consciousness) knows to be "all" (sarvam). Once the independency of the self is recognized, all ordinary ideas of abundance and power are considered as belonging to the state of being subject to another (anya). As a consequence, knowledge of the self does not mean "release" from the world of corporeal existence, but to be its ruler since all the elements that constitute the world belong to the self. In the ChU, kāmacāra is not based on having free access to the different worlds in the afterlife, but on knowing that the elements of corporeal existence are realms of the self who is both, the ruler and the ruled, the producer and the product. It is an idea of the self as being characterised by power and independence, which is here propagated irrespective of any idea of a higher, incorporeal realm of existence, and as if unconcerned about any karmic repercussions such "self-indulgence" may have.

\section{Kāmacāra in the Mahābhārata: Uttara-Kuru and the freedom of women}

The idea of the individual self as a powerful, autonomous entity has not prevailed in subsequent Sanskrit literature. Instead, other interpretations of the self seem to have become dominant, such as its being an entity devoid of agency (akriya), and its existing immovably in a realm beyond "all worlds" in Sāṃkhya or Yoga doctrines, or as a state of merging into the absolute in Advaita Vedānta. ${ }^{23}$ Yet, the idea that the pathways that result in the knowledge of the self imply the experience of a state of unprecedented empowerment and independence has never been completely discarded even in those traditions which insist on the self's transcendence and immovability. Almost all ascetic traditions, for example Yoga and Buddhism as well as philosophical traditions such as Sāmkhya, which teach the "self" as being an entity beyond the worlds of desire, include the attainment of a state of command and freedom (usually called aiśvarya, vibhūti or siddhi) in their descriptions of the pathway to the "highest goal". However, it is usually a state that one needs to pass through when one wants to move on to still

23 In the monotheistic theologies of the bhakti-traditions starting with BhG this state of absolute freedom and power is reserved for the one and only highest god or goddess. Yet, states of god-like empowerment may be ascribed to accomplished devotees in some traditions, such as the Pāśupata tradition (see Hara 1999). In the large spectrum of tantric doctrines and practices empowerment plays a particularly important role as well. 
higher levels of existence. Therefore, the attainment of such a state is almost always accompanied with a warning not to stay in it, not to indulge in kāmacāra. As in ChU 8, it is a state that is obtained when ordinary ideas of pleasure, freedom and plenitude have been transformed or relinquished, yet it is no longer the final stage of the knowledge of the self. Other ideas of the self prevail in later traditions, and higher states of existence are envisioned which surpass the worlds of the Vedic gods, of brahmaloka or of the self indulging itself within itself. Nevertheless, affirmations of the alternative and probably older idea are still to be found in later texts, in particular in the Mahābhärata epic (MBh). There are strong resemblances between Vedic descriptions of kāmacāra and depictions of the powers of Yogins (bala, vibhūti) in some epic texts. ${ }^{24}$ Elsewhere, the self is in some contexts (still) depicted as having, in certain situations, free access to the objects of the corporal world. ${ }^{25}$ However, while the idea of doing as one pleases and of freely roaming the worlds is very much present in these texts, the expression kāmacāra is not. Instead, it occurs in other contexts, particularly when it is used in order to characterise a specific region of a cosmos, whose limits by now have been extended beyond the sun, the moon and brahman. This points to the changing ideological framework in which realms and qualities other than the worlds of the Vedic gods or "following one's own pleasure" were considered more valuable in many of the doctrines included in the epic. Still, the idea of kämacāra has not been completely discarded, as can be seen in the two texts from the MBh which shall be discussed in the following. ${ }^{26}$

24 For an analysis of such texts, see Malinar 2012.

25 For instance, Bhagavadgitā 15.13-15 on the "embodied self" as "ruler" (see Malinar 2007a: 203-204). Such depictions are connected with the idea of the "large self" (mahān ātman) in some Upanișadic texts (see van Buitenen 1964), the principle of mahat in Sāṃkhya philosophy and a state called "sarvabhūtātman"; for the latter see below.

26 The compounds kāmacāra (five times) and kāmacārin (twenty times) occur in the MBh twenty-five times. In addition we find kāmacara five times and once, at 9.45.22, kāmacarī is used as a proper name. When ascribed to human beings these compounds characterize in particular women, emphasizing either their freedom $(1.113 .4,13.105 .26)$ or their lustfulness $(8.27 .85,8.30 .55)$. The latter, negative connotation of kāmacāra is also ascribed to Duryodhana (7.77.13) and generally to those "indulging in sensual pleasures" (14.26.15; similar is 12.93.10, 15.14.16; this applies also to god Indra at 13.4.19). Kāmacāra is also depicted as a state or capability that accrues to those obtaining higher cosmic regions (13.72.6, 13.85.64, 13.105.26, 13.111.69, 13.111.92, 94). Furthermore, it is an attribute of Garuda (1.27.3) and the right of free movement claimed by the Gandharvas (1.158.3). It is used for describing the mobility of divine or demonic chariots and other possessions $(2.8 .3,3.17 .1,5.98 .15,12.191 .4)$, and is a characteristic feature of the horse set free in the Aśvamedha sacrifice (14.71.12, 14.77.43, 14.84.2, 14.86.1). At 12.170.13 kāmacara is used to praise the freedom of the man who lives in poverty, while at 4.6 .8 it can be understood in the sense of "following the wish of another". In the latter passage Yudhișthira introduces himself at 


\subsection{The Dialogue between Gautama und Indra}

The first text is included in the thirteenth book of the epic, the Anuśāsanaparvan, one of the so-called "didactic" books. In a series of discourses on ritual duties and the results of one's deeds, King Yudhișțira turns to his dying grandfather Bhīsma with the following query. He has heard that there is only one (after-) world (eka loka; 13.105.1) for those doing good deeds (sukrtin) and now wonders whether there is diversity (nānātva) in the after-life, that is, if there are different worlds for those who passed away. In his reply, Bhișma first of all corrects the basic assumption and points out that there is not "one world" for the virtuous, but that they go to various worlds, good and bad, which people obtain according to their deeds (karman). In order to illustrate this, Bhīṣma relates a dialogue that once took place between the Brahmin Gautama and the god Indra, who appeared to the Brahmin in the guise of King Dhṛtarāștra. Once, Gautama had adopted and lovingly raised a baby-elephant who had lost its mother. One day, when the grown-up, extremely strong elephant roamed the forest, King Dhṛtarāștra captured him. Gautama protested bitterly against what he felt to be a shameful betrayal among friends. In compensation the king offered the Brahmin 1000 cows, 100 female slaves and five gold necklaces, and he argued that Brahmins have no use for elephants which belong to the royal class. Therefore, taking the elephant does not imply any adharma, or breach of norms yielding negative consequences (13.105.13). Gautama retorts that he will seek retaliation in the world of Vaivastava (Yama), where good and bad deeds are compensated. There, he will take the elephant away from the king. Dhṛtarāșțra points out that he will not be found in Yama's abode, but in a higher or other (para) world. With this reply there begins

the court of King Virāța as a Brahmin who seeks protection and patronage from the king and promises to obey the former's wishes. Elsewhere in the epic the compound chandacārin is used for such situations. For instance, at MBh 1.148.11 chandacārin is contrasted with kämaga when the idea is questioned that Brahmins should be dependent on anyone and comply with another's wishes (chandacārin) "since they are free to go as they chose, like birds, they are motivated to settle down by the qualities [of place]" (gunair ete hi vāsyante kāmagāh pakșino yathā). Complete freedom is described using the expression svachandacārin in a remarkable passage on the perfect age in MBh 3.181.12-15, when men had just been created and did just what they wished to do: "They all foregathered in heaven with Gods as it pleased them (svacchandena), then went back to earth again as the fancy took them (svacchandacärinah). Those men died when they wanted (svacchandamaranāha), and lived when they wished (svacchandajivinah), they were unoppressed (alpabādhāh), free from pain, fulfilled, and unobstructed.” (tr. van Buitenen) Then "in the course of time" men became restricted to moving on earth only (prthivitalacārinah h. Interestingly kāmacāra does not occur at all in the Rāmāyaṇa, wherein one finds kāmaga (nineteen times), mostly as an attribute of divine or miraculous carriages which "move freely" or "at will"; in the MBh this compound is used for similar purposes twenty-eight times. 
a description of the different worlds in which Gautama will search for the king. It seems that the description of worlds mirrors a hierarchical taxonomy characterized by the obtainment of ever "higher" worlds which is indicated by the gods presiding over these worlds and the increase of ascetic and meditative practices. Thus, the description starts with the region of the Mandākinī river (heavenly Gangā), belonging to god Kubera (13.105.18), and ends with the world of brahman to be reached by those engaged in Yoga meditation (13.105.52). Each time the king replies that he will not be found in any of these regions. Eventually, Gautama understands that he is not speaking to King Dhṛtarāșțra, but to the god Indra, who, as he correctly points out, can be found at the places where the best Vedic sacrifices are performed. He declares that he will find Indra there and take the elephant (13.105.54-55). Pleased that Gautama has recognized him, Indra offers him the elephant as a reward for his cleverness, which Gautama accepts.

This dialogue offers not only a variation of the well-known topic of the rivalry between a king and a Brahmin with respect to a prestigious and emblematic animal, ${ }^{27}$ but also an interesting description of the different worlds and of those who obtain them. The dialogue-partners play a complementary role in providing this information. While Gautama depicts the individual worlds and their inhabitants, the king explains who will obtain them. One of the regions is that of the UttaraKurus which is described immediately after the region of the forest of the sage Nārada, which is reached by those fond of singing and dancing (13.105.23). One of the characteristic features of Uttara-Kuru is the state of kāmacāra, as is pointed out by Gautama: “There, where the beautiful Uttara-Kurus shine forth as they are enjoying themselves together with the gods, $\mathrm{O}$ king, where sages reside who were born from fire (sacrificial fire) or from the mountains - hence not born from a womb -, where Śakra (Indra) rains down all pleasures, where women live doing what pleases them (kāmacāra) and where there is no jealousy between men and women - there I will have the elephant returned to me." ${ }^{28}$ In his reply IndraDhṛtarāștra describes who will reach this place: "This world is for those who have withdrawn their desires with respect to all beings, who live without eating meat and who have discarded the means of punishment and do not harm either mov-

27 In the well-known story about the King Viśvāmitra who wants to obtain the miracle cow of the Brahmin sage Vasistha, the king wants to appropriate a "brahmanical" animal. In the present dialogue, a "royal" animal is taken by a king from a Brahmin. The conflict is resolved by turning the elephant into a gift which the Brahmin receives as a reward from a king who is in reality Indra. In this way both sides get their due.

28 yatrottarāḥ kuravo bhānti ramyā devaih sārdham modamānā narendra / yatrāgniyaunāś ca vasanti viprā hy ayonayah parvatayonayaś ca // 13.105.25 / yatra śakro varșati sarvakāmān yatra striyaḥ kāmacārāś caranti / yatra cerșyā nāsti nārīnarāṇām tatra tvāham hastinaṃ yātayișye //13.105.26/. 
able or immovable beings since they are among the beings who have become the self of all beings (sarvabhūtātmabhūta). They have no hopes, no egotism since they have given up all passions, and they are indifferent towards praise or blame, be there success or failure. This world only belongs to those with such precepts, 0 Great Sage - Dhṛtarāșțra will go somewhere else, not to this world.”29

This depiction of Uttara-Kuru as a land of pleasure inhabited by humans and gods alike is here connected to its being also a kind of "gender utopia" where the usual parameters of (marital) ownership and their consequences (jealousy for instance) complicating the relationships between the sexes do not apply. This is presented as being intrinsically connected to the situation that the women of this region are free to do what they want, they are ones to whom kāmacāra is ascribed. When compared with the Upanișadic texts, the chances of obtaining the freedom to follow one's own pleasure has now been reduced to just one cosmic region, and within this region it applies solely to women. It is neither a characteristic feature of the self nor a quality that accrues to a sacrificer reaching one of the heavenly worlds. Yet, when one looks at the requirements for obtaining this realm, echoes of the depiction of the self in the ChU can be detected. It is explained that Uttara-Kuru is obtained by those who have relinquished the conventional ways of pursuing desire and "have become the self of all beings" (sarvabhütätmabhūtāh). The latter characterization is elsewhere in the epic connected to achievements of Yoga practice which resemble the recognition of the self as being "all” (sarvam) in ChU 7 (see above). "Being the self of all beings" is, for instance, in Bhagavadgitā 5.7 described as a state of both cosmic empowerment as well as detachment, which implies that one has the elements of the material world at one's disposal and is able to act without karmic repercussion (see also MBh 12.231.19-23). ${ }^{30}$ However, while the preconditions for obtaining kāmacāra are still connected to high levels of accomplishment with respect of the knowledge of the self, the attainment itself is no longer indicative of the ultimate level of happiness and plenitude. It is now just a state among others, being connected to one particular region and one group of its inhabitants only. ${ }^{31}$ The ascription of kāmacāra to the women of Uttara-Kuru indicates that its interpretation differs

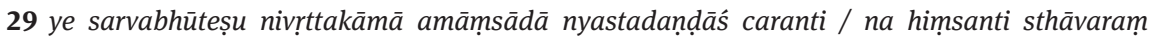
jañgamaṃ ca bhūtānām ye sarvabhūtātmabhūtāḥ //13.105.27 / nirāsișo nirmamāvītarāgā lābhālābhe tulyanindāpraśaṃsāḥ / tathāvidhānām eșa loko maharṣe parạ̣ gantā dhṛtarāș̣tro na tatra //13.105.28/.

30 For a discussion of the compound sarvabhütātman in the Bhagavadgitta and elsewhere in the epic, see Malinar 2007a: 111-116.

31 Elsewhere in MBh 13 kāmacāra is mentioned as a reward for correct ritual or lawful activities to be obtained in heavenly regions; see 13.72.6, 13.110.69, 13.110.92. 
considerably from that in the earlier texts. First of all, the semantic spectrum of kāma has been reduced to "sexual desire" or "love", and thus the freedom envisioned here in particular concerns gender-relations and their social institutions. It can be assumed that the latter were already (or about to be) firmly established in their typical patriarchal and patrilineal forms in the period of the composition of the epic. These put a large number of restrictions on women in particular, by denying them svatantratā, "self-dependent", autonomous forms of living in all phases of their life. ${ }^{32}$ This precludes not only any idea of sexual liberties or taking sexual partners outside the institution of marriage, but also subjects a woman to being dependent (paratantra) on her male relatives, in particular her husband. This dependency extends to the afterlife, when husband and wife reappear together in one of the heavenly worlds they obtained as the reward for their merits, and when "following the husband" into his heavenly world is depicted as a desirable goal for married women. The epics provide examples for both. ${ }^{33}$ This implies that for the wife the state of asvatantratā (dependence) continues as well; also for the husband marriage as "community of dharma (lawful acts and the merits that accrue from them)" (sahadharma) applies to the after-life. ${ }^{34}$ Against this background, the description of Uttara-Kuru with its "women following their own pleasure" can be read also as an alternative to the ideas of the continuation of "dependent existence" of women in the afterlife. In this way the state of kämacāra is again connected to freedom in the sense of independence, and of not being subject to another (svatantra, svarāj), a characteristic feature of kāmacāra in the $\mathrm{ChU}$, as we have seen. However, it is now a rather special case since it seems to

32 For a paradigmatic formulation of this notion, see Manusmrti 5.148 and 9.2.

33 In the MBh, for instance, Mādrī (1.116) follows her husband via immolation on the pyre (see also below). At 16.8.71 and 16.6.68, wives of Kṛṇa do the same and supposedly reappear in some heavenly world where they are still (dutiful) wives. For an instance of parent-child reunion, see Rāmāyaṇa 2.57: After King Daśaratha had accidentally killed their son, the latter's parents announce that they will follow their deceased son when he appears to them in a heavenly body. This confirms the general idea of the desirability of following a departed or deceased beloved person in the next life. However, as is pointed out by Sutherland (1994), this not intrinsically gender-oriented idea has particularly restrictive, misogynist repercussions for women. With respect to the epic, Sutherland notes: "the practice of following one's husband must be seen [...] as the normative mode of behaviour sanctioned for women" (1994: 1599). This practice, like the counter-idea of women being kāmacāra, is deeply embedded in the larger framework of patriarchal constructions of gender which aim at subjecting female sexuality and confining female agency through the ties of kinship structure and norms of purity.

34 In MBh 13.19.1-9 Yudhișțira expresses his anxiety that the rule of "sahadharma" in marriage would also apply in the after-world even though each partner acted quite differently, since women are known to be "false" (anrta). 
hold an attraction for women only; it seems to be taken for granted that in the heavenly world a certain amount of kāmacāra is allowed to men.

\subsection{Dialogue between Kuntī and Pāṇḍu}

The specific understanding of kāmacāra and the implications of its being applied to women are also addressed in a dialogue between Queen Kuntī and her husband Pāṇdu in the first book of the MBh (1.111-113). Here, gender-relations become an issue between two central protagonists of the epic, whose marriage does not exactly follow the ideal-typical model propagated in the law-books. In this dialogue between Kuntī and Pāṇụ, two important narrative threads laid out in the previous chapters become intertwined. Firstly, events in Kuntī's pre-marital life now enter her marriage, in particular her being in possession of a mantra which allows her to call upon any god she wants. Up to now she had used this mantra only once for summoning the god Sūrya (the sun-god), which resulted in the birth of her son Karṇa, whom she abandoned (MBh 1.104). Secondly, Pāṇụ has become effectively impotent and is in danger of remaining without offspring because he was cursed by a sage - disguised as a deer - that he will die when having sexual intercourse with his wives. This situation provides the narrative framework for the dialogue since Pāṇụ, in reaction to the curse, had decided to become an ascetic and embarked with his wives to the forest. ${ }^{35}$ When he is invited by other ascetics to join them for a meeting with the gods in some heavenly region Pāṇu points out that he cannot come along. He lacks a male heir and is therefore not allowed to enter the heavenly worlds. The sages ask him to think about a solution, and Pāṇu finds it in the teachings of the laws which apply in times of distress (äpaddharma). They show a considerable flexibility with respect to defining kinship relationships, in particular, legitimate offspring.

With this information, Pāṇdu approaches Kuntī and talks to her about the different sorts of offspring known to the teachers of law (dharma), which include also offspring begot by one's wife from other men (1.111.22-32). Pāṇdu turns to his wife with the following request: "Therefore, lacking myself the power of progeny, I shall now send you. Find yourself a child by my equal or better, glorious wife!" 36 He illustrates his request with a story about the wife of a warrior-hero who was

35 For a discussion of the story of Pāndu within the larger context of dealing with "oedipal conflicts” in the epics and the parallels to the story of King Kalmāsapāda (MBh 1.173), see Goldman 1978: 358-359.

36 tasmāt praheșyāmy adya tvāṃ hīnaḥ prajananāt svayam / sadṛśāc chreyaso vā tvaṃ viddhy apatyam yaśasvini // 1.111.32/ tr. van Buitenen (emphasis in the original). 
ordered by her husband to receive a son from a Brahmin ascetic (1.111.33-36). However, Kuntī did not welcome this idea and she tells her husband that he should not talk to her like this (1.112.2). She explains that she will follow him to the heavenly world and demands that he comes to her for offspring. This request, if fulfilled, implies that Pānḍu will die (due to the curse) and Kuntī will eventually follow him. Kuntī's position echoes the curse of the deer / sage which also includes the woman with whom Pāndu has intercourse (1.109.28-29). The curse suggests that the woman will be as well in the grip of the death and she will follow the king "out of devotion" (bhaktyā) ${ }^{37}$ It is against this background that Kuntī rejects the idea of "going to another man" since no man could compare to Pāndu and because she is ready to share her husband's fate. In order to substantiate her position, Kuntī relates a "lawful, ancient story" (dharmyā paurāṇ̄ kathā; 1.112.6) about the mighty King Vyusitāśva and his wife Bhadrā, who were very much in love with each other ( $k \bar{a} m a y \bar{a} m$ āsatus tau parasparam; 1.112.16). However, due to his being completely intoxicated by lust for his wife the king soon died from consumption. A shattered Bhadrā - holding her husband's corpse tightly (śavam samparișvajya; 1.112.29) - lamented bitterly and declared that she wants to give up her life, which appears useless to her as she is bereft of her husband and left without a son. Then she heard a hidden voice (i.e. the husband's) asking her to get up and prepare herself to have intercourse. Kuntī concludes the story by pointing out that in this way the queen begot with the corpse (śavena) seven sons. Then, she turns to her husband with the following suggestion: "Likewise you too can beget sons on me mentally (manasā) because you are endowed with the power of asceticism and yoga." 38 In this way, the post-mortem sexual relations between Queen Bhadrā and her late husband are transposed into the register of Yoga-powers, which allows for creating offspring "mentally" - an idea obviously familiar to Kuntī (as well as the epic's audience).

In his reply, Pāṇụu addresses only indirectly the method suggested by his wife. He does not comment on the issue of his ascetic-yogic powers as the solution to their problem, but rather rejects any comparison between himself and King Vyusitāśva by placing the latter in "former times" and regarding him as being on par with the gods (1.113.2). The latter, of course, can do such thing as

37 Mādrī will be the one to find herself in this situation after Pāṇ̣u had forced her to have sexual intercourse. She wins the argument with Kuntī about who will be the one to mount Pāndu's funeral pyre (see MBh 1.116 and note 33).

38 tathā tvamapimayy eva manasā bharatarșabha/śaktojanayituṃ putrāṃs tapoyogabalānvayāt (MBh 1.112.34) The compound tapoyogabala can also be rendered "lasting yogic powers of your austerities" (van Buitenen) or "power through the practice of asceticism". The latter weakens the terminological meaning of the word yoga as a specific set of Yoga doctrines and practices. 
begetting offspring with artificial or non-corporeal devices (as Pāṇdu will soon also learn from his wife). ${ }^{39}$ Being faced with his wife's resistance to the method he has proposed for procuring an heir, Pāṇu turns to the issue of the subordination of women. He does so by telling Kuntī of a "law of old" (dharma purāna) that was taught by the sages who knew dharma and which ordained that women are independent (svatantra) and may follow their own desire (kāmacāra): "Formerly, women were unrestrained it is said, my lady with the beautiful face, enjoying themselves by following their own pleasure, being independent, $\mathrm{O}$ you with the charming eyes. No negative consequences accrued to them who, since their youth, were unfaithful towards their husbands as this was the law in ancient time, my virtuous wife. Even today, those creatures born as animals conform to this very law, the ancient one, as they are devoid of desire and hate, ${ }^{40}$ and this law, taught in the olden days, is honoured by the great seers. It still applies among the Uttara-Kurus, my dear with the delicate thighs, as this law, which is favourable for women, is eternal." ${ }^{1} 1$ However, continues Pāṇụu, a new moral rule (maryā $\bar{a}$ ) was soon established in the present world (1.113.8), a rule restricting the freedom of women by subjecting them to the commands of their husbands. This implies that kāmacāra can now be viewed as immoral, "lustful" or "hedonistic" behaviour. ${ }^{42}$ He tells her the story of how this happened and concludes that

39 The king seems not to be prepared to relinquish or risk his life by having intercourse with his wife to procure an heir - another, at least theoretical, option which is, perhaps, very indirectly hinted at by Kuntī, when she declares herself to be ready to follow him into the heavenly world and asks him to come to her for offspring. The quality of Pāndu's asceticism (and also the power of the curse) can be seen in that he finally succumbs to sexual desire and dies after having forced his younger wife Mādrī to have intercourse with him (MBh 1.116). As no offspring results from this final sexual encounter Pāṇu dies without a son of the "first class" category listed by lawteachers (i.e. begotten by himself with his own wife).

40 This connection between animals and behaving freely is in this passage interpreted positively as signifying the absence of negative emotions and the ideas of possession that go along with them. In other instances, animals are depicted as being totally subject to lust and therefore as belonging to a lower class of beings. This view is used in negative depictions of women (and other lustful beings), who "shamelessly" follow their pleasures; see, for instance, MBh $8.27 .85-86$.

41 anāvṛtāḥ kila purā striya āsan varānane / kāmacāravihāriṇyạ̣ svatantrāś cārulocane //1.113.4 / tāsāṃ vyuccaramāṇānāṃ kaumārāt subhage patīn / nādharmo 'bhūd varārohe sa hi dharmaḥ purābhavat //1.113.5/ taṃ caiva dharmaṃ paurāṇam tiryagyonigatāḥ prajāh / adyāpy anuvidhīyante kāmadveșavivarjitāḥ / purāṇadṛșto dharmo 'yaṃ pūjyate ca maharșibhị̣ //1.113.6/ uttareșu ca rambhoru kuruṣv a dyāpi vartate / strīnām anugrahakarạ̣ sa hi dharmah sanātanah /// 1.113.7/.

42 See for instance MBh 7.77.13 when Kṛṣna criticizes Duryodhana as a mean (kșudra) and lustful (kāmacāra) man (see also 12.93.10 for a king), or 13.40.19 when Indra is depicted as "following his desires with women of other men" (parastrīkāmacārin). In 14.26.15, a kāmacārin is defined as 
the "old stories" about ancient laws and lawful practices have no authority in the present even though they are "eternal" (sanātana), that is, do not lose their legitimacy in principle. Therefore, he has the right to demand from his wife that she obey him without further questions.

The line of argument presented here seems quite remarkable as it works with the idea of the historicity of dharma as a process in which "eternal laws" may lose their authority, but are not completely lost. An "eternal" law ordained by the sages has become invalid only in a certain sense, namely, that it has lost its ubiquity but not its rightfulness as such. An "eternal” law is subject to history insofar as it was once generally valid, but now only applies to certain regions and particular groups of beings. Thus, while an eternal law that favours women and grants them free movement and choice is still "somewhere" valid, it has no authority in the here and now. Instead, a maryādā has been established, a rule demarcating the boundaries of appropriate conduct, which prescribes that adultery ${ }^{43}$ is now an offence on a par with "killing an embryo". By the same rule, a wife is now bound (niyukta) to one husband and when she refuses his command to conceive a child she is guilty of the same offence (1.113.17-19). This implies that when the husband commands his wife to go to another man in order to produce offspring, she does not commit adultery. Therefore, Pāṇdu explains, a wife must always do what her husband tells her, irrespective whether it conforms the law or not (dharmyam adharmyam vā; 1.113.27). On his injunction (niyoga), Kuntī should conceive sons with a "twice-born of superior ascetic power" (1.113.30). In the context of this dialogue, the interpretation of kāmacāra is now embedded in a distinctly "legal" framework regulating gender, and more specifically marital relations. The element connecting this interpretation with ideas of freedom and "self" is the issue of svatantratā, independence from others, which in the epic is embedded in a legal framework. Uttara-Kuru is again depicted as a region in which laws of possession do not rule social relationships. ${ }^{44}$

\footnotetext{
"addicted to the pleasure of the senses" (indriyasukhe rata) and is contrasted with the one who keeps his observances. The women of "barbaric" kingdoms are blamed for kāmacāra and other undesirable behaviour by Karṇa at MBh 8.27.85-86 and 8.30.54-55.

43 For a probing analysis of a discourse on "straying" wives in the MBh, see Fitzgerald 2010, 39-47.

44 Uttara-Kuru is also described in other texts as the land of milk and honey. Bhattacarya (2000) views Uttara-Kuru as being the Indian idea of “(E)utopia”, of living in a "happy state” of primitivism, or rather "tribal communism" (Bhattacarya 2000:199), where there is neither private property nor the institution of marriage. The emphasis on the freedom enjoyed by women in the epic resembles the depiction of Uttara-Kuru in the Buddhist Canon. In the Āțānattiya Suttanta it is pointed out that Uttara-Kurus do not think egotistically (amama) and in terms of property (apariggaha); see Dīgha-Nikāya 32, 7; Vol. 3: 199). While amama is interpreted in the commentary
} 
Seen from the angle of the dialogue-structure, it can be said that quite a twisted argument has been voiced by Pāṇụu in order to break his wife's resistance against his demand that she should "go to other men". Kuntī did not make "faithlessness" the issue, but rather that it is for her inconceivable to have sons by any other man, in particular, if he is of lower status than her husband. The story about King Vyuṣitāśva and his wife Bhadrā points also to kāma (love and passion) as a further motif for Kuntī's insistence on Pāṇdu as the father of her sons. The task for Pāṇụ seems to lie in presenting the idea of having intercourse with some "other man" as being neither adultery nor a licence for female independence, but as the act of the ever faithful, devoted wife who does not question her husband. This constellation may explain why Pāṇu interprets both the story of the post-mortem intercourse between King Vyuṣitāśva and his wife as well as the idea of women's kāmacāra, of their following their own desire, as belonging to a distant past. The days of women acting and moving freely are gone, at least in the present world, and continue only among the Uttara-Kurus. The reference to the Uttara-Kurus thus serves to dispel any idea that "here and now" adultery is anything but an offence. Therewith, the idea that women could do what they want, which includes refusing to obey their husbands, is also rejected as is made very clear in the explanation of the new moral rule (maryādā), which ties (niyukta) a woman to a husband and subjects her to his commands, even if they are unlawful and produce no merit. In this way, the absolute dependence on the husband is presented as a counter-reaction against the former freedom granted to women by an "eternal" law that "favours women". All this obviously needs to be brought home to Kuntī, who seems to entertain her own ideas about her status as the wife of Pāṇụu and about what is appropriate and not. ${ }^{45}$

However, the argument is not over; the dialogue does not end with Kuntī having been put in her place, but rather with an affirmation of the fact that she has choices other than the "ascetic twice-born" suggested by her husband. It turns out that she has her own form of kāmacāra, as she now reveals to her husband, and this, in particular, dispels her concern that she has to go to another man of lower status. She now tells her husband about a collection of mantras she has obtained in her youth from the Brahmin Durvāsas as a reward for her perfect

of Buddhaghosa as referring to the possession of things like ornaments and food, apariggaha refers to the non-possession of women, in particular, in marriage (Sumañgala-Vilāsinī III: 965). 45 This dialogue between Kuntī and Pānụu has some remarkable structural parallels to the one which unfolds in the next generation, and thus at a later point of the epic narrative, between Draupadī and Yudhișthira (MBh 3.28-33; see Malinar 2007b), and is thus another example of how gender-relations are negotiated in the epic. This cannot be analyzed further in the context of this paper. 
guest-service: “The adorable called me and gave me as a boon a collection of mantras (mantragrāma) endowed with magical power (abhicārasamyukta) and he instructed me as follows: 'Whichever god you will invoke with the mantra he, if he wants or not, will come into your power!'"46 The nature of the mantras at Kuntī's disposal is revealed in their being connected to abhicāra (power of enchantment), and thus to practices which aim at subjugating others. ${ }^{47}$ Using such mantras is also a method for pursuing one's desire and, as Durvāsas stresses, every god must comply, whether he wants it or not (akāmo vā sakāmo vā). Pāṇụu readily agrees to Kuntī's suggestion to use this method, and he chooses God Dharma as the first to be called up by Kuntī through offerings and enchanting mantras (upacārābhicārābhyām; 1.113.42). God Dharma, wanting to or not, indeed appears yogamūrtidhara, "having the body of a Yogin" or "assuming a yogic body" (van Buitenen). Whatever meaning of yoga is taken here, it can be safely assumed that it is an "artificial" body created for this occasion which disappears when it has fulfilled its purpose. This appearance of the god Dharma in a Yoga body matches Kuntî's earlier discourse on begetting children through yogicascetic power.

All the events narrated here and the discourse between king and queen are presented to the audience against the background of their knowing that it is not the first time Kuntī has used her mantras, as she had called up the sun-god before her marriage; a fact she will never disclose to her husband. In leaving her husband to choose the god to be called upon for producing offspring, Kuntī makes her collection of mantras, which allows her to freely summon any god, available to the legitimate context of her marriage. The mantras save her from the fate of having to put up with a man not matching her husband in status. The story of Kuntî's earlier employment of the mantras, which led to the birth of Karna (MBh 1.104), can be read as a comment on what happens if the power to subject others to one's own wishes is not confined to an afterlife, or to a distinct cosmic region, or a past epoch in the history of dharma, but when it is tested "out of curiosity". The possession of mantras imbued with enchanting power allows subduing others who are considered suitable for obtaining one's goals, but it is possibly

46 sa me 'bhicārasamyuktam ācașța bhagavān varam / mantragrāmaṃ ca me prādād abravīc caiva mām idam //1.113.34 / yaṃ yạ̣ devaṃ tvam etena mantreṇāvāhayiṣyasi / akāmo vā sakāmo vā sa te vaśam upaișyati //1.113.35 /.

47 Abhicāra also means "incantation" or "black magic" against enemies, which is not implied in the passage under discussion (see also Mehendale 2008). However, it is also made clear that the mantras allow wielding power over those invoked because they have abhicāra, that is, incantatory power. In this connection it is significant that abhicāra is not at all mentioned in the account of this story in MBh 3.287-292 which generally tends to downplay Kuntī’s agency. 
dangerous and eventually detrimental to pursuing true interests. The text under discussion demonstrates in its own way the importance of understanding kāmacāra as a state in which possession and subjecting others has come to an end.

\section{Final remarks}

In analysing the occurrences of kämacāra in Vedic texts and the MBh some remarkable shifts in the meaning as well as the contexts, in which the compound is used, can be observed. In Vedic literature kämacāra is connected to a state of happiness and freedom to be obtained by a sacrificer in the after-life. It is connected to a notion of immortality characterized the fulfilment of all desires and free choice of another birth. In the ChU, the state of kämacāra becomes connected to the notion of the "self" (ätman) as an autonomous entity that owns the elements which constitute it. Knowing oneself as the "self" that is "all" (sarvam) becomes the basis for kāmacāra. This means that one is neither subject to another who restricts one's freedom, nor dependent on possessing or commanding others for defining one's completeness and power. Kämacāra is a feature of a notion of "self" (ātman) that emphasizes autonomy and plenitude. This notion is different from ideas of immortality prominent in ascetic teachings that are often associated with immovability and changelessness as the characteristic features of "liberation" (mokșa, mukti) as a state beyond pleasure and desire.The successful dissemination of ascetic teachings on the extinction of all desires and the new interpretations of ritual action and individual agency (karman) did not result in completely removing the Vedic idea of a state of "Wandeln nach Wunsch" ("following one's pleasure") from the spectrum of salvific ideas, but rather in its being reframed and reinterpreted vis-à-vis "higher" goals. ${ }^{48}$ This can be seen in the epic when kāmacāra is in some instances still considered a state of freedom which is primarily defined as not being subjected by others. Yet, kāmacāra is no longer exclusively and positively viewed as a state signifying immortality and self-rule, but is reduced to a quality to be obtained in certain cosmic regions. In particular, it accrues to women when they dwell in the region of Uttara-Kuru; kāmacāra becomes a feature of their being independent (svatantra) in following their desires and, more specifically, in the choice of their sexual partners. Furthermore, it is con-

48 While the "fulfilment of all desires" is in the context of Vedic ritual an ideal state, ascetic discourse calls for their relinquishment. Yet, in some of the ascetic traditions this goes along with a promise of an exceptional happiness (sukha). This is particularly true of early Buddhism and Yoga. 
nected to an idea of the life enjoyed by women before the rule was established that a woman is subject to one husband and asvatantratā (dependency) becomes the paradigm and law of her social existence. In the present time referred to by the epic composers, women following their pleasure would be seen as committing adultery. The changing view of kämacāra is also discernible in its acquiring a negative connotation when it is used in the epic for depicting "loose" and "lustful" characters.

The semantic shifts can be connected to ideological as well as social changes texts which literary texts such as the MBh echo, imagine and reflect upon at various levels. On the one hand, the semantic shifts are indicative of the growing influence of ascetic religions that propagate "liberation" (mokșa) from corporal existence and karman as the highest goal. On the other hand, the peculiar connection of kāmacāra with women in the MBh demonstrates that the notion of freedom associated with independence and a self-determined life is now delineated with respect to constructions of gender and patrilineal kinship that seem to have been in a process of solidification when the epic was composed. The older association between "following one's desire" and a state of independence (svatantratā) is still at play when kämacāra is used to depict female autonomy which is now available in the (after-life) region of Uttara-Kuru only. In a social structure in which dependency rules the life of women - not only in this world, but also in the after-world - female independence and freedom of agency can be propagated and imagined as a reward to be obtained by women upon death due to the merits they obtain through ascetic and meditative practices. The "utopian" character of this attainment highlights not only the hegemony of certain constructions of genderrelations and patrilineal kinship (as documented, for instance, in the Dharmasāatra literature), but also their being intertwined with ongoing debates and imaginations about the social as well as soteriological place of individual desire ( $k \bar{a} m a)$ and freedom. From a soteriological point of view a favoured way of integrating the quest for powerful autonomy and fulfilment of desires is to turn it into an "attainment" (siddhi) on the pathway to the "highest goal". When negotiating kāmacāra and svatantratā with respect to the social world it becomes connected, on the one hand, to ritual and ascetic practices recommended for obtaining certain after-worlds and, on the other hand, to constructions of gender. Neither in Vedic literature nor in the epic is kämacāra associated with the semantics of mukti and mokșa - the terms frequently used for the freedom that accrues through "liberation" or "release" from the world(s) - but with the terms svatantratā and svarāj, that is, independence and self-rule in this world as well as in the after-life. 
Acknowledgments: I am grateful to James L. Fitzgerald and Sally J. Sutherland Goldman for their valuable comments on an earlier version of this paper.

\section{Bibliography}

Bhattacharya, Ramkrishna (2000): “Uttarakuru: The (E)utopia of Ancient India”. Annals of the Bhandarkar Oriental Research Institute 81: 191-201

Brown, C. Mackenzie (1984): “Svarāj, the Indian Ideal of Freedom: A Political or Religious Concept?”. Religious Studies 20.3: 429-441.

van Buitenen, J. A. B. (1964): “The Large Ātman”. History of Religions 4: 103-114.

van Buitenen, J. A. B. (1973-78): The Mahābhārata translated and edited. Vol. 1-3. Chicago: Chicago University Press.

Deussen, Paul (1921): Sechzig Upanișad's des Veda aus dem Sanskrit übersetzt. Leipzig: Brockhaus.

Dīghānikāya (1947): The Dīghā-Nikāya. Edited by A. E. Carpenter, 3 Vols., London: Pali Text Society ( $\left.1^{\text {st }} 1911\right)$.

Fitzgerald, James L. (2010): “The boy 'Slowpoke' as a deep thinker: In defence of 'straying' wives against father's uxoricidal rage”. In: Epic and Argument in Sanskrit Literary History. Edited by S. Pollock, New Delhi: Manohar: 31-59.

Goldman, Robert P. (1978): “Fathers, sons and Gurus: oedipal conflict in the Sanskrit Epics”. Journal of Indian Philosophy 1: 325-392.

Hara, Minoru (1999): "Pāśupata and Yoga. Pāśupata-Sūtra 2.12 and Yogasūtra 3.37". Asiatische Studien 53: 593-608.

Horsch, Paul (1971): "Vorstufen der indischen Seelenwanderungslehre". Asiatische Studien 25: 99-157.

Jamison, Stephanie / Brereton, Joel (2014): Rigveda, the Earliest Religious Poetry of India, 3 Vols. Oxford: Oxford University Press.

Kunst, Arnold (1976): “Indeterminism versus Determinism: The Seventh Prapāțhaka of the Chāndogya Upanișad". Journal of the Royal Asiatic Society of Great Britain and Ireland 1976: 67-72

Mahābhārata (1933-59): The Mahābhārata for the first time critically edited by a Board of Scholars. 18 Vols., Poona: Bhandarkar Oriental Research Institute.

Malinar, Angelika (2007a): The Bhagavadgïtā: Doctrines and Contexts. Cambridge: Cambridge University Press.

Malinar, Angelika (2007b): “Arguments of a Queen: Draupadī’s Views on Kingship”. In: Epic Constructions: Gender and Narrative in the Mahābhārata. Edited by S. Brodbeck and B. Black. London: Routledge, 79-96.

Malinar, Angelika (2012): "Yoga Powers in the Mahābhārata”. In: Yoga Powers: Extraordinary Capacities Attained Through Meditation and Concentration. Edited by K.A. Jacobsen. Leiden, 33-60.

Manusmṛti (1983): Manusmṛti with the Sanskrit commentary Manvartha-Muktāvalī of Kullūka Bhațta. Edited by J. L. Shastri. Delhi.

Mehendale, M. A. (2008): “ Kuntī’s Relation with Durvāsas”. Annals of the Bhandarkar Oriental Research Institute 89: 129-132. 
Oertel, Hanns (1896): “The Jāiminīya or Talavakāra Upanișad Brāhmaṇa”. Journal of the American Oriental Society 16: 79-260.

Olivelle, Patrick (1998): The early Upanișads: annotated Text and Translation. Oxford: Oxford University Press.

Proferes, Theodore (2007): Vedic Ideals of Sovereignty and the Poetics of Power. New Haven: American Oriental Society.

Rāmāyaṇa (1960-75): The Vālmīki-Rāmāyaṇa, The National Epic of India, critically edited for the First Time. Edited by G.H. Bhatt et al., 7 Volumes. Baroda: Oriental Institute.

Rgveda (1994): Rig-Veda, a metrically restored Text with an introduction and notes by Barend van Nooten and Gary B. Holland. Cambridge (Mass.): Harvard University Press.

Schmithausen, Lambert (1995): “Mensch, Tier und Pflanze und der Tod in den älteren Upanișaden”. In: Im Tod gewinnt der Mensch sein Selbst. Das Phänomen des Todes in asiatischer und abendländischer Religionstradition. Herausgegeben von G. Oberhammer. Wien: Österreichische Akademie der Wissenschaften, 43-74.

Sumañgalavilāsinī (1971): The Sumañgala-Vilāsinī. Buddhaghosa's Commentary on the Dīgha-Nikāya edited by W. Stede, Three Parts, London: The Pali Text Society 1971 (1 $1^{\text {st }}$. 1932).

Sutherland, Sally J. (1994): "Suttee, Sati, and Sahagamana: An Epic Misunderstanding". Economic and Political Weekly 29.26: 1595-1605.

Thieme, Paul (1971): “Der Weg in den Himmel nach der Kaușītakī-Upanișad”. In: Paul Thieme, Kleine Schriften, Bd. 1. Herausgegeben von G. Budruss. Wiesbaden: Harrassowitz, 82-99. 